\title{
Atlantoaksial rotasjonsfiksasjon - en årsak til torticollis
}

BAKGRUNN En sjelden, men viktig årsak til torticollis hos barn er atlantoaksial rotasjonsfiksasjon. Dersom pasienten går udiagnostisert i mer enn tre måneder, er kirurgi som oftest eneste behandlingsalternativ. I denne artikkelen presenterer vi våre erfaringer med operativ behandling av sent diagnostisert atlantoaksial rotasjonsfiksasjon hos barn.

MATERIALE OG METODE Artikkelen er basert på en gjennomgang av journaler til pasienter som ble operert for atlantoaksial rotasjonsfiksasjon i Nevrokirurgisk avdeling ved Oslo universitetssykehus, Rikshospitalet, i perioden 2004-10.

RESULTATER Materialet består av seks barn i alderen 7-14 år. Fem hadde vært utsatt for et mindre traume mot øvre nakkeregion, en hadde hatt øvre luftveisinfeksjon. Diagnosen ble stilt 5-36 måneder etter symptomdebut. Hos tre av de seks pasientene ble det fors økt lukket reponering uten resultat. CT-undersøkelse et år postoperativt viste normalstilling i atlantoaksialleddet hos to pasienter og delvis reposisjon hos tre. Hos den siste var det beinet fusjon på operasjonstidspunktet, og åpen reponering var mislykket. Alle hadde redusert rotasjonsbevegelighet i nakken ved kontroll etter ett år.

FORTOLKNING Alle våre pasienter fikk stilt diagnosen mer enn fem måneder etter symptomdebut. Full eller delvis reposisjon ble oppnådd hos fem av seks.

Atlantoaksial rotasjonssubluksasjon er en sjelden tilstand som første gang ble beskrevet av sir Charles Bell i 1830 (1). Den opptrer stort sett kun hos barn (2-4) (fig 1). Når subluksasjonen i atlantoaksialleddet vedvarer og gir torticollis, kalles den atlantoaksial rotasjonsfiksasjon $(5,6)$. I litteraturen brukes atlantoaksial rotasjonssubluksasjon og -fiksasjon dels om hverandre (7). Kronisk atlantoaksial rotasjonsfiksasjon defineres typisk som en rotasjonsfiksasjon med en varighet på over 2-3 måneder (7). Tilstandens hyppighet er lite omtalt i litteraturen. I et materiale på 288 barn med torticollis hadde kun to verifisert atlantoaksial rotasjonsfiksasjon (8). Pasientene fremtrer med torticollis der hodet er lagt over mot en side og rotert til den andre siden og med lett fleksjon i nakken. Denne hodestillingen er helt typisk og blir kalt cock robin-posisjonen $(3,6,9-11)$, idet den minner om hvordan rødstrupen holder hodet når den lytter etter mark (fig 2).

Den utløsende årsak kan være et mindre nakketraume, infeksjon i øvre luftveier (Grisels syndrom) eller kirurgiske prosedyrer i svelg og nakkeregion $(3,9,12-16)$. Hos én av fire er det ingen kjent årsak (9). Pasienten har ofte moderate smerter når hodet blir holdt i ro, mens bevegelser mot normal stilling utløser smerter (13). Nakke- og hodesmertene avtar vanligvis etter hvert, mens skjevstillingen tiltar (9).

Bestemte radiologiske kriterier for å kunne stille diagnosen atlantoaksial rotasjonsfiksasjon ble utarbeidet i 1979 og er basert på opphevet eller betydelig redusert bevegelighet mellom atlas og axis ved rotasjon i nakken under dynamisk CT-skanning (17). Littera- turen gir imidlertid ikke noe entydig svar på i hvilken grad bevegeligheten mellom atlas og axis reduseres (18). Normalt er atlantoaksialkomplekset ansvarlig for $60 \%$ av rotasjonen i nakken og atlantooksipitalleddet for $3-8 \%$, den resterende rotasjonen finner sted nedenfor axis (11). Atlantoaksialleddet er stabilisert av ligamentum transversum, som hindrer overfleksjon, og alarligamentene, som hindrer overrotasjon (3). Patofysiologien ved atlantoaksial rotasjonssubluksasjon/-fiksasjon er ufullstendig forstått. En kombinasjon av høy elastisitet i ligamenter samt mer horisontalt beliggende fasettledd hos barn kan være predisponerende faktorer. I tillegg har barn en mer konveks formet øvre leddflate på axis som artikulerer med den nedre konkave leddflaten til atlas, og processus uncinatus er dårlig utviklet. Sammen kan dette tillate større bevegelsesutslag, spesielt for rotasjon og sidebøyning $(3,9)$. Hos barn er også hodet større i forhold til nakken enn hos voksne, og muskulaturen er dårligere utviklet. En kombinasjon av dette kan være årsaken til at tilstanden nesten utelukkende forekommer hos barn (19).

Atlantoaksial rotasjonsfiksasjon kan inndeles i akutt og kronisk type (7). I de akutte tilfellene reponeres ofte feilstillingen spontant $\mathrm{i}$ forbindelse med undersøkelse eller ved enkle konservative tiltak, som innebærer smertestillende og antiinnflammatorisk medikasjon $(7,10)$. Hos de resterende vil forsiktig manuell traksjon og etterfølgende nakkekrage som regel føre til reposisjon, selv om enkelte får tilbakefall og må behandles på ny (9). Dersom diagnosen blir stilt for sent, kan imidlertid subluksasjonen mellom atlas og axis bli irreversibel.

\author{
Jarle Sundseth \\ jarle.sundsetharikshospitalet.no \\ Jon Berg-Johnsen \\ Nevrokirurgisk avdeling \\ Sigrun Skaar-Holme \\ Radiologisk avdeling \\ Mark Züchner \\ Frode Kolstad \\ Nevrokirurgisk avdeling \\ Oslo universitetssykehus, Rikshospitalet \\ I \\ Engelsk oversettelse på www.tidsskriftet.no \\ e-fig 6 finnes i Tidsskriftets elektroniske utgaver
}

\section{HOVEDBUDSKAP}

I perioden 2004-10 ble seks barn operert for atlantoaksial rotasjonsfiksasjon ved Oslo universitetssykehus, Rikshospitalet

Alle fikk diagnosen mer enn fem måneder etter symptomdebut

Man oppnådde full reposisjon hos to og delvis reposisjon hos tre, mens åpen reponering og kirurgisk fiksasjon ikke lot seg gjøre hos den siste

Ett år etter operasjonen hadde alle nedsatt rotasjonsbevegelighet i nakken 


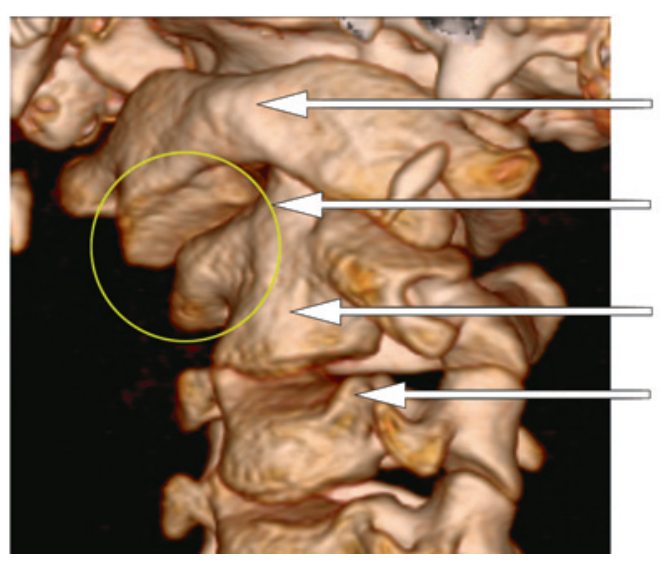

Fremre atlasbue

Høyre atlantoaksialledd [fasettledd]. Atlas er luksert frem på axis

Corpus på axis

Processus uncinatus $\mathrm{C} 3$

Figur 1 Subluksasjon av høyre atlantoaksialledd, sett fra venstre side/forfra

Atlantoaksial rotasjonsfiksasjon er tidligere blitt omtalt i Tidsskriftet (20). Fortsatt går for mange barn lenge med udiagnostisert torticollis, derfor ønsker vi å minne om tilstanden og behandlingen. I denne artikkelen presenterer vi våre erfaringer med operativ behandling av sent diagnostisert atlantoaksial rotasjonsfiksasjon hos barn. Klinisk presentasjon, radiologiske funn og kirurgisk behandling blir diskutert på bakgrunn av litteraturen.

\section{Materiale og metode}

Vi har gått gjennom journalene til pasienter operert for atlantoaksial rotasjonsfiksasjon ved Nevrokirurgisk avdeling, Oslo universitetssykehus, Rikshospitalet, i perioden 2004-10. Pasientene ble funnet etter søk på diagnosekode og ved gjennomgang av aktuelle operasjonsbeskrivelser. Vi gikk også gjennom journalene til alle som hadde vært innlagt med diagnosekoden torticollis i samme periode og fant ikke flere enn de seks som ble operert og som blir omtalt i denne artikkelen.

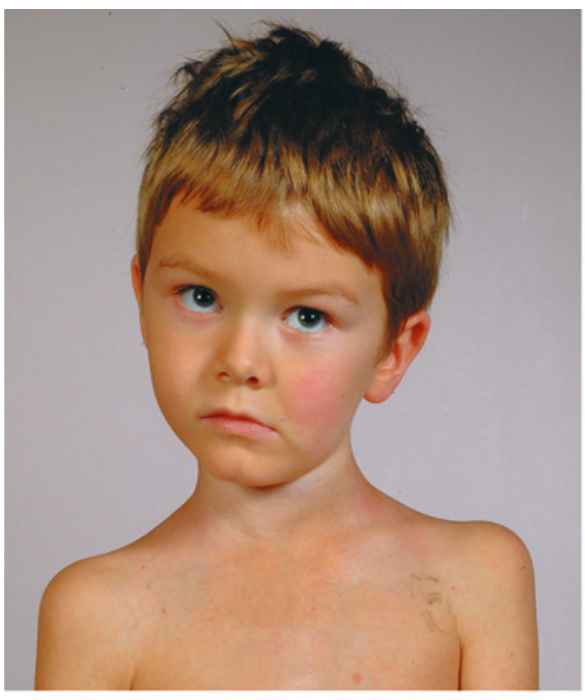

Figur 2 al Cock robin-feilstilling, benevnt slik fordi den kan likne rødstrupens stilling når den lytter etter mark (b). Hodet er deviert til én side med rotasjon til motsatt side og fleksjon (C1 lukserer frem på C2). Pasienten og hans foreldre har gitt samtykke til at bildet blir publisert
Operasjonsteknikkene som ble benyttet var ulike bakre fiksasjonsmetoder mellom atlas og axis, bl.a. Gallies fusjon (titanvaier og beinkloss fra hoftekam) (fig 3) og Harms teknikk (fiksasjon med skruer og stag på begge sider) (fig 4). Operasjonsteknikk ble valgt ut fra den enkelte pasients anatomi. Det var i hovedsak de beinede forhold og risikoen for å skade a. vertebralis som avgjorde hvilken teknikk som ble brukt. $\AA$ bruke titan- eller stålvaier og bein fra hoftekammen anses i dag som gammeldags, men dette er allikevel gode teknikker (21) og benyttes hos oss der skruefiksasjon anses som for risikabelt eller uegnet. Videre kan det være betydelige sideforskjeller hos den enkelte pasient slik at skruefiksasjon bare lar seg gjøre på én side, men allikevel med stabil nok fiksasjon til at dette velges fremfor tidligere mer brukte metoder som f.eks. Gallies fusjon.

Fem av pasientene fikk tilpasset stiv nakkekrage og én fikk halovest (fig 5), som de brukte i 8-12 uker postoperativt. Pasientene har vært fulgt klinisk og med CT-kontroll i

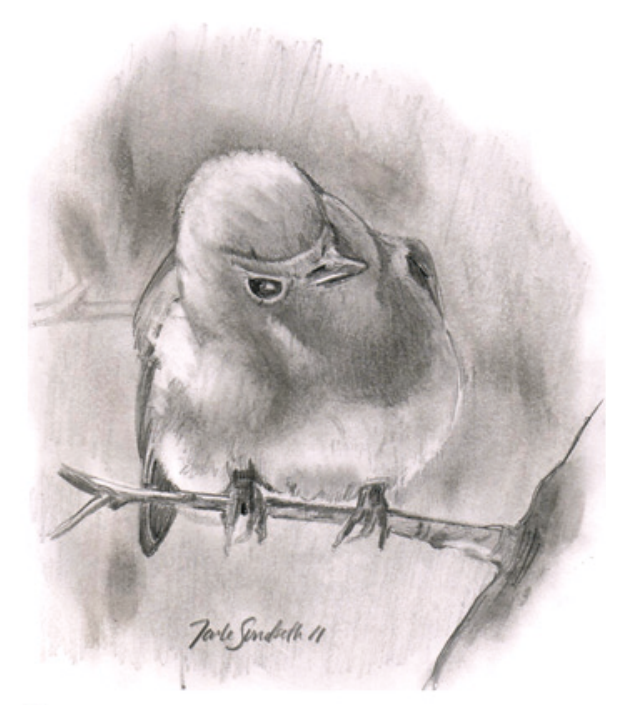

b minimum ett år. Journaldata som rapporteres er fra dette første året postoperativt.

\section{Etiske overveielser}

Personvernombudet ved Oslo universitetssykehus, Rikshospitalet, har godkjent bruk av persondata til denne artikkelen. De pårørende har gitt informert samtykke til bruk av sykehistorie og bilde. De pasientene som er over 12 år, har i tillegg gitt eget skriftlig samtykke.

\section{Resultater}

Seks barn, tre jenter og tre gutter i alderen 7-14 år, ble operert. Fem av dem hadde $\mathrm{i}$ forkant vært utsatt for et mindre nakketraume, én hadde hatt en øvre luftveisinfeksjon (tonsillitt). CT-undersøkelse viste feilstilling i atlantoaksialleddet hos alle. Graden av feilstilling, vurdert på CT-bildene, varierte (tab 1). Den ene pasienten hadde preoperativt en totalluksasjon i atlantoaksialleddet på den ene siden (e-fig 6).

Diagnosen ble stilt 5-36 måneder etter symptomdebut. Hos tre av barna mistenkte man juvenil revmatoid artritt før CT-undersøkelse med tredimensjonal rekonstruksjon viste subluksasjon i atlantoaksialleddet. To av disse tre fikk senere diagnosen juvenil revmatoid artritt.

Tre av pasientene ble først forsøkt reponert lukket med skallestrekk (GardnerWells) i opptil 15 dager - uten at man oppnådde tilfredsstillende korreksjon av feilstillingen. Diagnosen hos disse ble stilt etter fem, fem og seks måneder. De øvrige tre pasientene, med diagnoseforsinkelse på henholdsvis fem, åtte og 36 måneder, gikk derfor rett til operasjon uten lukket reponeringsforsøk. Fem av seks pasienter ble fiksert kirurgisk. Den siste hadde en fiksasjon som ikke lot seg korrigere, og operasjonen ble avsluttet uten kirurgisk fiksasjon. Ingen alvorlige postoperative komplikasjoner $\mathrm{i}$ form av blødning, infeksjon eller nevrologisk utfall var registrert.

CT-undersøkelse gjort ett år etter operasjonen viste full reposisjon hos to og delvis reposisjon hos tre av pasientene som ble kirurgisk fiksert (tab 1), i tillegg beinet fusjon i fasettledd og/eller bakre strukturer (laminae og spinosi) hos alle. Den siste pasienten hadde beinet fusjon allerede på operasjonstidspunktet.

Ved ettårskontrollen ble det rapportert lite smerter, bortsett fra hos barnet som fikk diagnosen 36 måneder etter symptomdebut. Alle pasientene hadde en viss rotasjonsinnskrenkning i nakken ved klinisk undersøkelse. Der vi hadde oppnådd komplett reposisjon, var rotasjonsinnskrenkningen på ca. 25-30\% i begge plan. Ett av barna hadde fått gjentatte botoxinjeksjoner i m. sternocleidomastoideus på grunn av uttalt kontraktur i denne, uten at dette hadde gitt noen vesentlig effekt.

\section{Diskusjon}

I perioden 2004-10 ble seks barn i alderen sju til 14 år operert for atlantoaksial rota- 

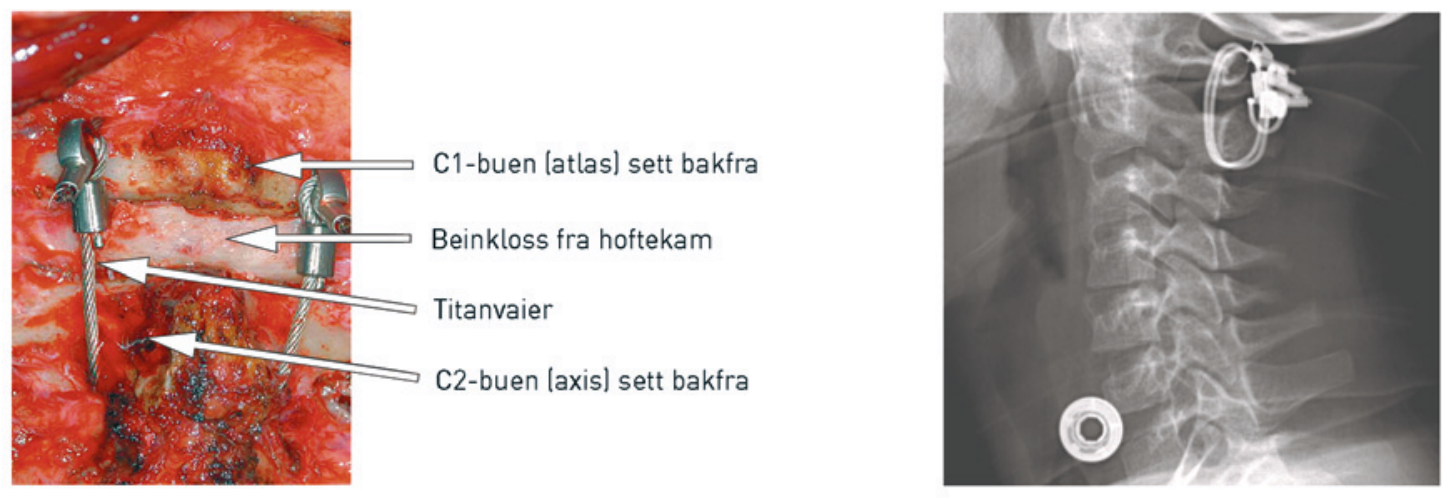

Figur 3 C1- og C2-buen fikseres til hverandre med ståltråd eller titanvaier på begge sider og beinkloss fra pasientens hoftekam imellom (Gallies fusjon). a) Peroperativt og b) røntgenbilde tatt fra siden

sjonsfiksasjon ved Oslo universitetssykehus, Rikshospitalet. Det ble oppnådd full reposisjon hos to og delvis reposisjon hos tre. Den siste hadde beinet fusjon på operasjonstidspunktet, og skaden lot seg ikke korrigere kirurgisk.

Fem av våre seks pasienter hadde vært utsatt for et mindre nakketraume, mens den siste hadde hatt tonsillitt. I et større materiale var tilstanden vanligst relatert til øvre luftveisinfeksjon $(35 \%)$, mindre traume $(20 \%)$ eller kirurgisk prosedyre i svelg eller nakke $(20 \%)$, i resten av tilfellene var årsaken ukjent (9). Mens det mannlige kjønn er overrepresentert ved spinale skader $(22,23)$, er det ved atlantoaksial rotasjonsfiksasjon en overvekt av jenter $-70-80 \%(9,23)$. I vårt materiale var halvparten jenter.

Før CT-undersøkelse var mulig var diagnostisering av atlantoaksial rotasjonsfiksasjon basert på konvensjonell røntgenundersøkelse (24). Resultatet er imidlertid ofte vanskelig å tolke hos et barn med feilstilling i atlantoaksialleddet $(6,24-26)$, men røntgenundersøkelse anses allikevel også i dag som et nyttig supplement $i$ utredningen for å utelukke annet patologisk, som medfødte misdannelser eller tumor i columna (27). Statisk CT-undersøkelse vil kunne vise feilstilling mellom atlas og axis, men den har

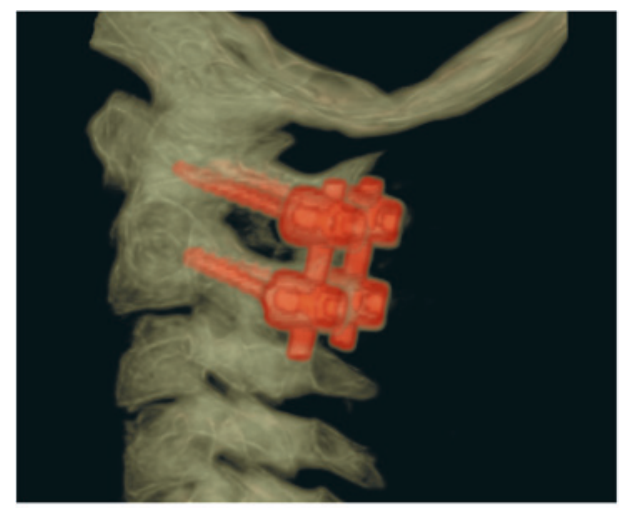

a

sin begrensning $\mathrm{i}$ at den ikke kan demonstrere den dynamiske sammenhengen mellom atlas og axis ved rotasjon $(27,28)$. Dynamisk CT-undersøkelse av et barn som roterer hodet maksimalt mot den ene siden vil som normalfunn vise at atlas roterer ca. $23^{\circ}$ på axis før denne begynner å rotere med atlas (29). For å verifisere en fiksert rotasjonsfeilstilling er dynamisk CT-undersøkelse, der bildene tas med hodet maksimalt rotert mot høyre, mot venstre og rett frem, det beste. Det er først da man kan se om feilstillingen i leddet lar seg korrigere ved rotasjon i nakken. Dersom feilstillingen/subluksasjonen endrer seg lite eller ingenting ved rotasjon, kan man radiologisk konkludere med atlantoaksial rotasjonsfiksasjon $(27,28$, 30). Undersøkelsen anbefales for kartlegging av de anatomiske forhold i øvre cervikalcolumna hos barn (31).

Torticollis hos barn kan ha ulike årsaker, og vedvarende skjevstilling bør alltid utredes nærmere. Hos barn er vanligste årsak kongenital muskulær torticollis (8). Denne tilstanden er forårsaket av kontraksjon og etter hvert kontraktur i m. sternocleidomastoideus på motsatt side av den hodet er rotert til. Slik krampe i muskulaturen finnes vanligvis ikke ved atlantoaksial rotasjonsfiksasjon (20). Imidlertid hadde vår pasient med totalluksasjon i atlantoaksialleddet kontraktur i muskulaturen. Hos tre av våre pasienter mistenkte man i forkant av operasjonen juvenil revmatoid artritt. To har senere fått diagnosen. Det er uvisst hvorvidt det er en sammenheng mellom tilstandene, men én teori er at rotasjonsfiksasjon kan oppstå som følge av slappere ligament og synovial fortykkelse ved juvenil revmatoid artritt (32). Samtidig forekomst er også beskrevet i en kasuistikk fra 2011 (33). Vi mener derfor det er viktig med bred utredning av barn med atlantoaksial rotasjonsfiksasjon for å utelukke juvenil revmatoid artritt. Dersom man ikke finner årsaken til torticollis hos barn, må tumor utelukkes. Tumor i bakre skallegrop kan komprimere/affisere nervestrukturer som innerverer nakkemuskulaturen og dermed sekundært gi torticollis (34).

De fleste tilfeller av torticollis forårsaket av ligament- eller muskelskade responderer godt på smertestillende og antiinflammatorisk medikasjon. Man oppnår oftest spontan bedring og normalisering av feilstillingen innen en uke (35). Når årsaken er atlantoaksial rotasjonsfiksasjon kan imidlertid tilstanden vedvare på tross av medikamentell behandling, eventuelt kragebehandling. Ved tidlig diagnose lar imidlertid også de fleste med denne tilstanden seg lett reponere luk-
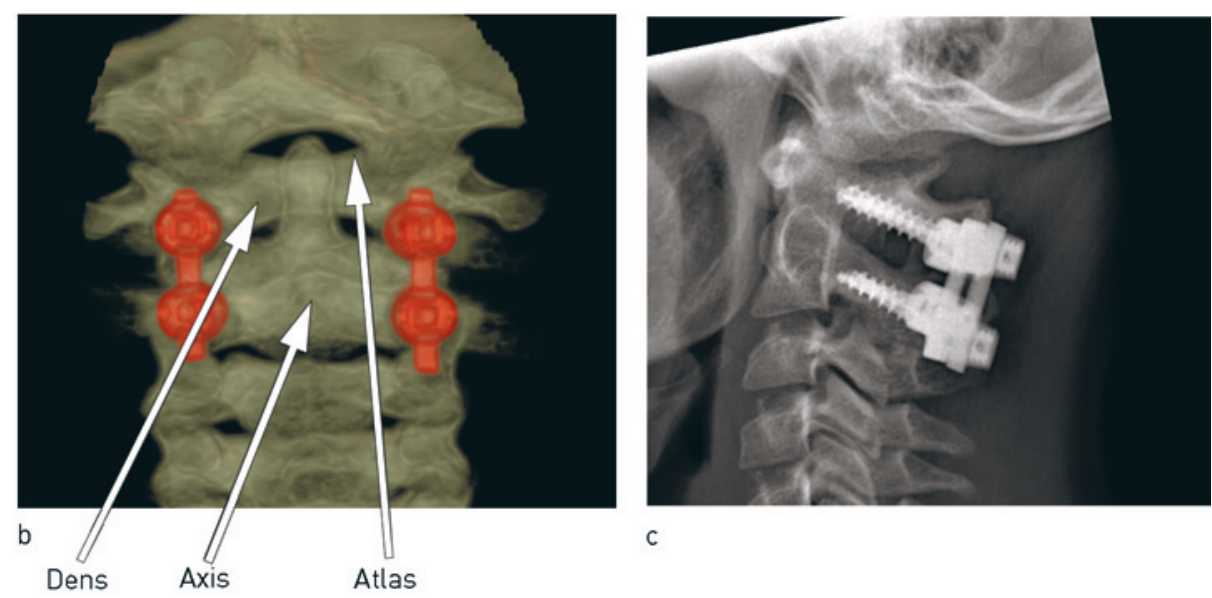

Figur 4 Atlas og axis er fiksert med skruer og stag på begge sider (Harms teknikk). CT-bilder fra a) siden og b) bakfra (der skruer og stag i atlas og axis er markert rødt). c) Vanlig røntgenbilde tatt fra siden 


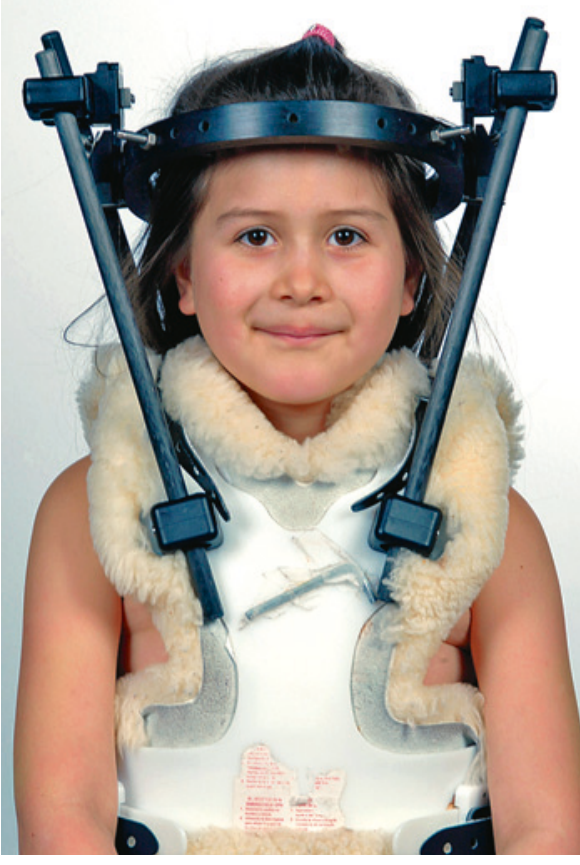

Figur 5 Postoperativ eksternfiksasjon i halovest. Pasienten og hennes foreldre har gitt samtykke til at bildet blir publisert

ket uten sekvele. Enkelte pasienter i tidlig fase oppnår til og med reposisjon under lett manipulasjon i forbindelse med undersøkelse og røntgendiagnostikk. Ved sykehistorie i opptil 30 dager bør antiinflammatorisk og eventuelt muskelrelakserende medikasjon i 1-2 uker kombinert med lett traksjonsbehandling og nakkekrage forsøkes (22). Traksjonsbehandling startet opp innen 30 dager etter symptomdebut fører i $90 \%$ av tilfellene til reponering og normal bevegelighet $\mathrm{i}$ atlantoaksialleddet (11).

Dersom det ikke blir reposisjon og bedring av smerter og bevegelighet, bør man gå videre med lukket reposisjonsforsøk med skallestrekk, fysioterapi og relaksantia. Pasientene ligger med skallestrekk i i gjennomsnitt to uker. Etter at det ved hjelp av CT-undersøkelse er bekreftet at feilstillingen er reponert, går pasienten med nakkekrage i seks uker. Den enkelte pasient relukserer imidlertid i gjennomsnitt to ganger (11), og enkelte anbefaler da nytt reponeringsforsøk $(9,22)$. Det er vist at i inntil 2-3 måneder etter oppstått torticollis er traksjonsbehandling kombinert med nakkekrage vanligvis tilstrekkelig for å oppheve feilstillingen $(6,9,36-38)$. Ved atlantoaksial rotasjonsfiksasjon over 2-3 måneder er gjerne lukkede reposisjonsforsøk mislykket $(9,36$, 38-40), og kirurgisk behandling med åpen reposisjon og intern fiksasjon kan bli nødvendig $(2,6,39,41,42)$.

Etter det vi kjenner til, er det kun gjort én prospektiv studie som omhandler diagnose, behandling og utfall ved atlantoaksial rotasjonsfiksasjon (42). Anbefalt behandlingsstrategi er ellers $\mathrm{i}$ all hovedsak basert på retrospektive oppfølgingsstudier.

Våre erfaringer med mislykket lukket reposisjonsforsøk hos tre pasienter med symptomvarighet over fem måneder er i tråd med rapporter om at skallestrekk ikke er tilstrekkelig til å kunne reponere en sent diagnostisert atlantoaksial rotasjonsfiksasjon $(14,37)$. Det kan være livstruende (2) og det er også beskrevet «plutselig død» ved forsøk på lukket reponering av en fiksert rotasjonsfeilstilling $i$ atlantoaksialleddet (6).

Kirurgisk behandling av atlantoaksial rotasjonsfiksasjon fører ikke til normalisering av de anatomiske forhold i nakken. Rotasjonsbevegeligheten etter fiksasjonskirurgi blir redusert med ca. $25 \%$ (6). Det er også vist at hos $30 \%$ oppstår en degenerasjonsprosess i nabonivået innen ti år etter fiksasjonskirurgi (16). Konsekvensene av mislykket repone- ring og vedvarende feilstilling er imidlertid så store at vi mener kirurgi er det beste behandlingsalternativet etter ett mislykket lukket reponeringsforsøk. Ved svært forsinket diagnose bør åpen reposisjon og fiksasjon gjøres uten først å forsøke lukket reponering.

Begrensninger i denne gjennomgangen skyldes et lite og selektert pasientmateriale, at dataene er innhentet retrospektivt og at vi ikke har hatt sammenlikningsgrupper. Å lage retningslinjer for behandling av denne pasientgruppen basert på vårt materiale blir således vanskelig. Det er imidlertid en internasjonal tendens $i$ retning av operativ behandling ved atlantoaksial rotasjonsfiksasjon $\mathrm{i}$ over tre måneder, selv om tidspunktet for anbefalt kirurgisk intervensjon varierer $(6,42)$.

Begge foreldre til alle barna og alle barn over 12 år har gitt samtykke til publisering av artikkelen.

\section{Jarle Sundseth (f. 1964)}

er spesialist i nevrokirurgi og overlege.

Forfatter har fylt ut ICMJE-skjemaet og oppgir ingen interessekonflikter.

\section{Jon Berg-Johnsen (f. 1955)}

er spesialist i nevrokirurgi, professor dr.med. og overlege.

Forfatter har fylt ut ICMJE-skjemaet og oppgir ingen interessekonflikter.

\section{Sigrun Skaar-Holme (f. 1971)}

er spesialist i radiologi og overlege.

Forfatter har fylt ut ICMJE-skjemaet og oppgir ingen interessekonflikter.

\section{Mark Züchner (f. 1972)}

er spesialist i nevrokirurgi og overlege. Forfatter har fylt ut ICMJE-skjemaet og oppgir ingen interessekonflikter.

Tabell 1 Seks barn operert for atlantoaksial rotasjonsfiksasjon ved Nevrokirurgisk avdeling, Oslo universitetssykehus, Rikshospitalet, i perioden $2004-10$

\begin{tabular}{|c|c|c|c|c|}
\hline & $\begin{array}{l}\text { Tid fra symptom- } \\
\text { debut til diagnose } \\
\text { (md.) }\end{array}$ & $\begin{array}{l}\text { Preoperativ } \\
\text { feilstilling } \\
\text { (grader) }\end{array}$ & $\begin{array}{l}\text { Postoperativ } \\
\text { feilstilling } \\
\text { (grader) }\end{array}$ & Operasjonsmetode \\
\hline Pasient 1 & 6 & 38 & 16 & $\begin{array}{l}\text { C1 fiksert til C2 med sublaminarvaier og autolog beinkloss } \\
\text { fra hoftekam (Gallies fusjon) }\end{array}$ \\
\hline Pasient 2 & 5 & 50 & 18 & $\begin{array}{l}\text { Atlantoaksial fiksasjon med skruer og stag kun på den ene } \\
\text { siden. Skrueplassering på den andre siden ble ansett som } \\
\text { for risikabelt ut fra fare for skade på a. vertebralis }\end{array}$ \\
\hline Pasient 3 & 8 & 8 & 0 & $\begin{array}{l}\text { Skruer i lateralmassivene i C1 og i pediklene i C2 på begge } \\
\text { sider, koblet med titanstag (Harms teknikk) }\end{array}$ \\
\hline Pasient 4 & 5 & $\begin{array}{l}\text { Totalluksasjon i leddet } \\
\text { C1/C2 på den ene siden. }\end{array}$ & 20 & $\begin{array}{l}\text { Fiksasjon med ståltråd som cerclage og autologt bein fra } \\
\text { hoftekammen }\end{array}$ \\
\hline Pasient 5 & 5 & 21 & 0 & Harms teknikk \\
\hline Pasient 6 & 36 & 16 & 16 & $\begin{array}{l}\text { Feilstillingen ble forsøkt reponert under operasjonen, men } \\
\text { det hadde allerede oppstått en autofiksasjon som ikke lot } \\
\text { seg korrigere. Operasjonen ble avsluttet uten videre kirurgisk } \\
\text { fiksasjon }\end{array}$ \\
\hline
\end{tabular}




\section{Frode Kolstad (f. 1960)}

er spesialist i nevrokirurgi, ph.d. og seksjonsoverlege ved Seksjon for spinalkirurgi.

Forfatter har fylt ut ICMJE-skjemaet og oppgir ingen interessekonflikter.

\section{Litteratur}

1. Bell C. The nervous system of human body, embracing papers delivered to the Royal Society on the subject of nerves. London: Longman, Rees and Orme, 1830: 403

2. Muñiz AE, Belfer RA. Atlantoaxial rotary subluxation in children. Pediatr Emerg Care 1999; 15: 25-9.

3. Sobolewski BA, Mittiga MR, Reed JL. Atlantoaxial rotary subluxation after minor trauma. Pediatr Emerg Care 2008; 24: 852-6.

4. El-Khoury GY, Clark CR, Gravett AW. Acute traumatic rotatory atlanto-axial dislocation in children. A report of three cases. J Bone Joint Surg Am 1984: 66: 774-7.

5. Wortzman G, Dewar FP. Rotary fixation of the atlantoaxial joint: rotational atlantoaxial subluxation. Radiology 1968; 90: 479-87.

6. Fielding JW. Hawkins RJ. Atlanto-axial rotatory fixation. (Fixed rotatory subluxation of the atlantoaxial joint). J Bone Joint Surg Am 1977; 59: 37-44.

7. Ishii K, Toyama Y, Nakamura M et al. Management of chronic atlantoaxial rotatory fixation. Spine 2012: 37: E278-85.

8. Ballock RT, Song KM. The prevalence of nonmuscular causes of torticollis in children. J Pediatr Orthop 1996; 16: $500-4$

9. Subach BR, McLaughlin MR, Albright AL et al. Current management of pediatric atlantoaxial rotatory subluxation. Spine 1998; 23: 2174-9.

10. Fernández Cornejo VJ, Martínez-Lage JF, Piqueras $C$ et al. Inflammatory atlanto-axial subluxation (Grisel's syndrome) in children: clinical diagnosis and management. Childs Nerv Syst 2003; 19: 342-7.

11. Pang D. Atlantoaxial rotatory fixation. Neurosurgery 2010; 66 (suppl 3): 161-83.

12. Grisel P. Enucléation de l'atlas et torticollis nasopharyngien. Presse Med 1930; 38: 50-4

13. Chiapparini L, Zorzi G, De Simone T et al. Persistent fixed torticollis due to Atlanto-axial rotatory fixation: report of 4 pediatric cases. Neuropediatrics 2005; 36: 45-9.
14. Schwarz N. The fate of missed atlanto-axial rotatory subluxation in children. Arch Orthop Trauma Surg 1998; 117: 288-9

15. Grøgaard B, Dullerud R, Magnæs B. Acute torticollis in children due to atlanto-axial rotary fixation. Arch Orthop Trauma Surg 1993; 112: 185-8.

16. Weisskopf M, Naeve D, Ruf M et al. Therapeutic options and results following fixed atlantoaxial rotatory dislocations. Eur Spine J 2005; 14: 61-8.

17. Rinaldi I, Mullins WJ jr., Delaney WF et al. Compu terized tomographic demonstration of rotational atlanto-axial fixation. Case report. J Neurosurg 1979; 50: $115-9$

18. Beier AD, Vachhrajani S, Bayerl SH et al. Rotatory subluxation: experience from the Hospital for Sick Children. J Neurosurg Pediatr 2012; 9: 144-8.

19. Kim YS, Lee JK, Moon SJ et al. Post-traumatic atlantoaxial rotatory fixation in an adult: a case report. Spine 2007: 32: E682-7.

20. Kvistad KA, Myhr G, Anda S et al. Atlantoaksial rotasjonsfiksasjon. Aktuell diagnose ved torticollis. Tidsskr Nor Lægeforen 1991; 111: 333-6.

21. Lowry DW Pollack IF Clyde B et al. Upper cervical spine fusion in the pediatric population. J Neurosurg 1997; 87: 671-6.

22. Martinez-Lage JF, Martinez Perez M, Fernandez Cornejo $\mathrm{V}$ et al. Atlanto-axial rotatory subluxation in children: early management. Acta Neurochir (Wien) 2001; 143: 1223-8.

23. Maheshwaran S, Sgouros S, Jeyapalan K et al. Imaging of childhood torticollis due to atlantoaxial rotatory fixation. Childs Nerv Syst 1995; 11 : 667-71.

24. Hicazi A, Acaroglu E, Alanay A et al. Atlantoaxial rotatory fixation-subluxation revisited: a computed tomographic analysis of acute torticollis in pediatric patients. Spine 2002; 27: 2771-5.

25. Johnson DP. Fergusson CM. Early diagnosis of atlanto-axial rotatory fixation. J Bone Joint Surg $\mathrm{Br}$ 1986; 68: 698-701

26. Murray JB, Ziervogel M. The value of computed tomography in the diagnosis of atlanto-axial rotatory fixation. Br J Radiol 1990; 63: 894-7.

27. McGuire KJ, Silber J, Flynn JM et al. Torticollis in children: can dynamic computed tomography help determine severity and treatment. J Pediatr Orthop 2002: 22: 766-70

28. Kowalski HM, Cohen WA, Cooper P et al. Pitfalls in the CT diagnosis of atlantoaxial rotary subluxation. AJR Am J Roentgenol 1987; 149: 595-600.

29. Pang D, Li V. Atlantoaxial rotatory fixation: Part 1 Biomechanics of normal rotation at the atlan- toaxial joint in children Neurosurgery 2004: 55 : 614-25, discussion 625-6.

30. Nicholson P. Higgins T, Forgarty E et al. Threedimensional spiral CT scanning in children with acute torticollis. Int Orthop 1999: 23: 47-50.

31. Bertozzi JC, Rojas CA, Martinez CR. Evaluation of the pediatric craniocervical junction on MDCT. AJR Am J Roentgenol 2009; 192: 26-31.

32. Haque S, Bilal Shafi BB, Kaleem M. Imaging of torticollis in children. Radiographics 2012: 32: $557-71$

33. Fusco MR, Hankinson TC, Rozzelle CJ. Combined occipitoatlantoaxial rotatory fixation. J Neurosurg Pediatr 2011: 8: 198-204.

34. Gupta AK, Roy DR, Conlan ES et al. Torticollis secondary to posterior fossa tumors. J Pediatr Orthop 1996; 16: 505-7.

35. Fleisher GR, Ludwig S, Henretig FM et al. Textbook of pediatric emergency medicine. 5. utg. Philadelphia, PA: Lippincott Williams \& Wilkins, 2006.

36. Ishii K, Chiba K, Maruiwa H et al. Pathognomonic radiological signs for predicting prognosis in patients with chronic atlantoaxial rotatory fixation. J Neurosurg Spine 2006; 5: 385-91.

37. Govender S, Kumar KP. Staged reduction and stabilisation in chronic atlantoaxial rotatory fixation. J Bone Joint Surg Br 2002; 84: 727-31.

38. Phillips WA, Hensinger RN. The management of rotatory atlanto-axial subluxation in children. J Bone Joint Surg Am 1989; 71: 664-8.

39. Crossman JE, David K, Hayward R et al. Open reduction of pediatric atlantoaxial rotatory fixation: longterm outcome study with functional measurements. J Neurosurg 2004; 100 (suppl spine 3): 235-40.

40. Mihara H, Onari K, Hachiya M et al. Follow-up study of conservative treatment for atlantoaxial rotatory displacement. J Spinal Disord 2001; 14: 494-9

41. Lee SC, Lui TN, Lee ST. Atlantoaxial rotatory subluxation in skeletally immature patients. Br J Neurosurg 2002; 16: 154-7.

42. Pang D, Li V. Atlantoaxial rotatory fixation: part 3-a prospective study of the clinical manifestation, diagnosis, management, and outcome of children with alantoaxial rotatory fixation. Neurosurgery 2005: 57: $954-72$

Mottatt 28.12. 2011, første revisjon innsendt 6.5. 2012, godkjent 27.11. 2012. Medisinsk redaktør Siri Lunde. 